\title{
The effect of government educational expenditure on labor productivity in Turkish manufacturing sector $^{* 1}$
}

\author{
Atakan Durmaz ${ }^{2}$, Hakan Pabuçcu ${ }^{3}$
}

\begin{abstract}
Labor productivity is very important phenomena to maintain the sustainable economic growth. Actually, there are many studies in the economic literature about determining the factors affecting labor productivity. At this point, this study aims to investigate the relationship between labor productivity and government educational expenditure by using the data covering the period of 1971-2015 for Turkey. To this aim, it is applied linear and non-linear autoregressive distributed lag model (ARDL). By using the bound testing approach, the long run relationship between variables has been investigated. Both models have been applied to determine whether the relationship between variables is linear or nonlinear. An asymmetric relationship between labor productivity and government educational expenditure was determined. For this reason, nonlinear model is preferred. The empirical findings indicate that positive changes in educational expenditure has negative effect on labor productivity and negative changes in educational expenditure has positive effect on labor productivity. The long run coefficient of openness is significantly positive; the short run coefficient of it is significantly negative for all lags. On the other hand, the effect of GDP growth on the labor productivity is significantly positive in both short and long run. While the effect of
\end{abstract}

* Received: 08-06-2018; accepted: 28-11-2018

1 This study is developed version of "The Effect of Government Educational Expenditure on Turkish Labor Productivity: A Bound Testing Approach" which was presented at "International Congress On Political, Economic And Social Studies" that organized in Sarajevo between 1922 May 2017.

${ }^{2}$ Assistant Professor, Faculty of Economics and Administrative Sciences, Department of Economics, Bayburt University, 69000 Bayburt, Turkey. Scientific affiliation: migration, labor market, international economics, Phone: +90458 211 1153/1496.E-mail: adurmaz@bayburt. edu.tr. (corresponding author).

${ }^{3}$ Assistant Professor, Faculty of Economics and Administrative Sciences, Department of Business, Bayburt University, 69000 Bayburt, Turkey. Scientific affiliation: machine learning, fuzzy logic, time series analysis. Phone: +9045821111 53/1403. E-mail: hpabuccu@ bayburt.edu.tr. 
average annual labor worked hours is significantly negative for the first two lags, it is significantly positive the last two lags in short run, it is positive but not significant in long run.

Key words: Labor productivity, openness, government educational expenditure, economic growth, non-linear ARDL

JEL classification: D24, H52, J24, O47

\section{Introduction}

Economic growth is one of the most fundamental economic problems that have been debated for centuries, from the individual who constitutes the smallest unit of society to the largest organization. Almost all of the mainstream economics schools on the solution of this problem have proposed an economic growth theory in their own way (Kocourek and Nedomlelova, 2018). These proposals, which were gathered around the "Neo Classical Growth Theories" in the early 20th century, show the inequality of factor accumulation among countries as the reason for the different rates of growth among countries (Solow, 1956; Cass, 1965). It is shown that there are differences among countries in various external factors such as saving rate (Solow, 1956), preferences (Koopmans, 1965) and/or technology as a source of this inequality experienced in factor accumulation.

Towards the end of the 20th century, the inability of the Neo Classical growth theories to explain the economic growth of the countries led to the development of new approaches called "Endogenous Growth Models" for the emergence of a wider concept of capital and the measurement of this capital in the 1980s. In general, these models have attempted to internalize the level of technological progress and savings by refusing to assume that the total production function has permanent effects on the economy. In this respect, they have hypothesized that the accumulation of scientific and technological knowledge, in other words, human capital stocks are the result of investments in research-development and /or education-training activities. According to Endogenous Growth Theories, investments in human resources have an impact on the productivity of other production factors. For this reason, each production factor leads to a higher total efficiency than the productivity. This is shown as a reason for rejecting assumptions about the law of diminishing or constant returns. (Lucas, 1988 and Romer, 1990).

However, in studies on the relationship between labor productivity and human capital stock in the following periods, conclusions that show that there is no significant, and even negative, relationship between them are reached in addition to those supporting the hypothesis of the theory (Pritchett, 2001; Barro and Salai-Martin, 2004). Some studies show that, as a fundamental cause of this situation, most work done through an international data act by assuming that the processes of schooling in different countries have the same returns (Temple, 1999 and Krueger and 
Lindahl, 2001). Whereas educational activities are often influenced by educational institutions and systems that differ between countries. It may also be argued that there are non-linear returns in the educational process, as the return of the education process is higher in countries with higher educated labor force (Azariadis and Drazen, 1990). According to some studies, the reason for this situation is that the investments made in education are not always related to productivity. In other words, education is not only an investment activity for an individual, but also a consumption activity (Benos and Karagiannis, 2016). Finally, it is emphasized that most of the skilled labor force is employed in the public sector, especially in the underdeveloped and developing countries, and that the return from the training process cannot be considered healthy because the production process in this sector is regulated by laws and regulations (Griliches, 1997).

It is expected that this study will contribute to the literature in two different perspectives. First, unlike other studies in the literature, the non-linear ARDL approach is used. This approach is preferred because it can be non-linear returns of the education process. One of the most important advantages of this approach is the investigation of asymmetrical effects in the model. In other words, it is to investigate the effects of both increases and decreases in independent variables on the dependent variable. An examination of the effects of increases and decreases in government educational expenditures on labor productivity separately is different from other studies in the literature.

Secondly, studies in the literature generally use growth of per capita income to measure labor productivity. But in this case, as stressed by Griliches (1997), the return of the majority of the labor force in the education process increased per capita income for developing countries such as Turkey are employed in the public sector is not a tool to reflect correct. For this reason, unlike other studies in the literature, this study uses the production level per labor force in the manufacturing sector to measure labor productivity.

The basic hypothesis of this work, which is prepared in the context of the literature on the subject, is that there is no short-run and long-run positive relationship between government educational expenditures and labor productivity, contrary to the hypotheses put forward by endogenous growth theories.

The study prepared in this direction consists of six main sections. Section 2 gives a short review of the literature on the relationship between human capital and labor productivity. Section 3 presents the theoretical framework and methodology being used in this study. Section 4 discusses the method used in analyzing the data. In Section 5, we discuss empirical results, and Section 6 concludes. 


\section{Literature review}

Towards the end of the 20th Century After the theory of "human capital" emerged in the forefront of economists such as Schults (1961), Becker (1964) and Mincer (1974), interest in education and its effects on economic growth has increased in the economic literature (Appiah and McMahon, 2002). At this point, the literature on the relationship between human capital and economy can be gathered under three headings. (I) Studies seeking that to demonstrate the positive effects of human capital on economic growth, directly and/or indirectly, based on the assumption of a complementary relationship between human capital and physical capital (Becker, 1964; Mincer, 1974; Lucas, 1988). (II) Studies that show that economic growth depends on the accumulation of human capital, which only creates new knowledge (Romer, 1990) and/or facilitates the adoption / imitation of foreign technologies (Nelson and Phelps, 1966). (III) Studies emphasize that the effect of economic growth of the human capital depends on the human capital accumulated during a certain period (Azariadis and Drazen, 1990).

As mentioned in the previous section, the empirical literature on the effect of human capital on labor productivity has different conclusions. This difference also manifests itself in the variables and methods used. In some studies, variables such as means years of schooling and expected years of schooling are used for representing the human capital, whereas in some studies investments on human capital such as education and/or health expenditures are used. A similar situation exists in the representation process of labor productivity. Some studies use economic growth or growth of GDP per capita as labor productivity, while others use output per labor force or income per labor force. As a result of all these differences, there are studies that emphasize that there is a positive relationship between human capital stock and labor productivity, as well as studies that show that there is no significant relationship between them and even a negative relationship.

Two of the most well-known studies that suggest a positive relationship between labor productivity and human capital are Lucas (1990) and Mankiw et al. (1992). In his study, Lucas (1990) stressed that investment in higher education, particularly in developing countries, should be invested in the field of higher education where high-skilled labor is needed to achieve sustainable economic growth, while investment in primary education has no effect on economic growth. Mankiw et al. (1992) found that there was a positive relationship between secondary and higher education graduate labor force and labor productivity in the study conducted using data from 121 countries between 1960-1985. Musila and Belassi (2004) concluded that the expenditure of labor per capita has a significant positive effect on economic growth both in the long run and in the short run in their study of the relationship between per capita education spending and economic growth in Uganda during the period 1965-1999. Blankenau et al. (2007) studied the long-run relationship between government educational expenditure and economic growth with the help 
of the data set covering 23 developed countries have reached the same conclusion as similar studies in the literature and have found a long and positive relationship between the two variables. However, unlike other studies, this study has reached the conclusion that this relationship is highly sensitive to budgetary constraints and that there is no significant relationship between government educational expenditure and economic growth when the exclusion effect of public expenditure is the case. Benos and Karagiannis (2016) found that different educational periods have different effects on labor productivity in their work using the dataset for regions of Greece from 1971 to 2011. Accordingly, labor productivity, which is a strong and positive relationship with higher education, has a negative relationship with primary education. There is no relationship between secondary education and labor productivity. Kocourek and Nedomlelova (2018) in a study of the effects of different education periods such as Benos and Karagiannis (2016) on labor productivity through a data set covering 125 countries from 1999-2014 have found similar effects between higher education and labor productivity, but have reached different conclusions in other categories of education. According to the results, unlike Benos and Karagiannis (2016), primary and secondary education have positive effects on labor productivity. Appiah (2017) found that there is a positive relationship between government educational expenditure in developing countries and labor productivity in a similar way to many studies in the literature, in the study of labor productivity on per capita income. Bokana and Akinola (2017) in their study of the effect of skilled labor on the total factor productivity with the help of data from the sub-Saharan African countries for the period 1981-2014, aimed to analyze the impact of tertiary education graduates, higher education output and productivity gap in the respective regions on productivity in certain countries in Sub-Saharan Africa. The researchers hypothesized that higher education graduates and higher education outputs are statistically significant positive effects on productivity in the selected sub-Saharan African countries. According to the results, the positive effect of higher education outputs on the total factor productivity is a statistically significant but negative effect of higher education graduates Ifa and Guetat (2018) have concluded that long and short run effects are different in the study of the effects of government educational expenditures on per capita income using data set of Tunisia and Morocco countries covering 1980-2015 period. According to this, although the impact of government educational expenditure on per capita income in the short run is positive in Morocco, it is negative in Tunisia. In the long run, the impact of government educational expenditure on per capita income is positive in both countries.

Some studies on the subject in the literature have reached different results between human capital and labor productivity. Studies such as Devarajan et al. (1996), Psacharopoulos and Patrinos (2004), Çoban (2004), Demir vd. (2006), Eriçok and Yılancı (2013), Çalışkan vd. (2017) have not found any relationship between educational expenditures and economic growth that they regard as labor 
productivity. However, some studies in the literature have found negative relations between educational expenditures and labor productivity. In this sense, Zeira (2009) argues that the mechanization process will have a negative impact on the wages of the skilled worker, in the study pointed out that as a result of technological developments, mechanization is increasingly emphasizing that labor force are taking their place in the production process, it is emphasized that this leads to a negative relationship between educational expenditures and economic growth. According to the results of the study, the increase in the cost of education could cause the economic growth to slow down and also cause the economic growth to cease altogether by creating a growth trap. In the study of Pelinescu (2015) examining the impact of human capital on the economic growth process using data from Romania and other European Union countries between 2000 and 2012, found that there is a negative relationship between the share of education expenditures in GDP and GDP per capita. Similarly, Wahab and Kefeli (2017) examined the effects of education and health spending on labor productivity in the study they have done using data from the Organization for Islamic Cooperation covering 1990-2015 period. According to the results of the study, health spending positively affects labor productivity, while educational expenditures decrease labor productivity. Şen et al. (2018) in their studies examining the relationship between educational and health expenditures and economic growth in eight developing countries through data for the 1995-2012 period, although they have determined a positive causality relationship between education and health spending and economic growth in Brazil and Mexico, they found a negative causality relationship for both education expenditure and health expenditure in Indonesia. No relationship was found in the study regarding the relevant variables related to other countries.

\section{Methodology}

The relationship between labor productivity and educational expenditure are examined by means of the traditional time series techniques such as cointegration, error correction or causality. These techniques assume short and long-run relationships between variables and that these relationships are symmetric. Only the investigation of symmetric relationships can be insufficient for the real world problems. For this reason, in order to investigate the symmetric and asymmetric effect of the educational expenditure on labor productivity it is applied both linear and nonlinear ARDL model. The linear ARDL model developed by Pesaran \& Shin, (1999; Pesaran, Shin, \& Smith, (2001) is a frequently used method for the investigation of linear relationships. The linear ARDL model was developed by Shin, Yu, \& Greenwood-Nimmo, (2014) to investigate asymmetric relationships and is referred to as NARDL in the literature. This approach focuses on the short and long-run asymmetric relationship between variables and investigates the effects of "negative" and "positive" changes in explanatory variables on dependent 
variables. It is considered the possible linear long run relationship between mentioned variables of the following form.

$$
\operatorname{lnprod}_{t}=\alpha_{0}+\alpha_{1} \text { Inexp }_{t}+\alpha_{2} \text { Inopen }_{t}+\alpha_{3} \text { Ingrw }_{t}+\alpha_{4} \text { lnhour }_{t}+\varepsilon_{t}
$$

In this model it is assumed that the labor productivity is a function of the government educational expenditure. Here, all variables are in the logarithmic form. In represents the natural logarithm. prod is the labor productivity of the Turkey, exp is the government educational expenditure (US dollars), open is the openness as \% of GDP, grw is the GDP growth rate and hour is the average annual hours actually worked per worker. In this respect, the estimates of the coefficients $\alpha_{1}$ could be negative or positive. If the sign of $\alpha_{1}$ is positive, an increase of the government educational expenditure leads to an increase in labor productivity otherwise, if the sign of $\alpha_{1}$ is negative, an increase of the government educational expenditure leads to a decrease in labor productivity.

It is incorporated both negative and positive changes of the government educational expenditure separately by adopting the model of Shin et al., (2014) in Eqn. 2.

$$
\begin{aligned}
& \operatorname{lnprod}_{t}=\alpha_{0}+\alpha_{1} \operatorname{lnexp}_{t}^{+}+\alpha_{2} \operatorname{lnexp}_{t}^{-}+\alpha_{3} \text { Inopen }_{t}+ \\
& +\alpha_{4} \operatorname{lngrw}_{t}+\alpha_{5} \text { lnhour }_{t}+\varepsilon_{t}
\end{aligned}
$$

In Eqn. 2, $\ln _{\exp }+$ and $\ln \exp _{t}^{-}$are positive and negative changes in government educational expenditure respectively; $\alpha=\left(\alpha_{0}, \alpha_{1}, \alpha_{2}, \alpha_{3}, \alpha_{4}, \alpha_{5}\right)$ is a vector of long run parameters to be estimated. $\operatorname{lnexp}_{t}^{+}$and $\ln _{\text {exp }}{ }_{t}^{-}$are a partial sum of processes of positive and negative changes defined in the following forms.

$$
\begin{aligned}
& \operatorname{lnexp}_{t}^{+}=\sum_{i=1}^{t} \Delta \operatorname{lnexp}_{t}^{+}=\sum_{i=1}^{t} \max \left(\Delta \operatorname{lnexp}_{i}, 0\right) \\
& \ln \exp _{t}^{-}=\sum_{i=1}^{t} \Delta \ln \exp _{t}^{-}=\sum_{i=1}^{t} \min \left(\Delta \operatorname{lnexp}_{i}, 0\right)
\end{aligned}
$$

Depending on the formulation in Eqn. 2 the long run relationship between labor productivity and government educational expenditures increases is $\alpha_{1}$ and decreases is $\alpha_{2}$ are expected to be negative-positive respectively. It is expected that $\alpha_{1}>\alpha_{2}$.

Following the Shin et al., (2014), extended model can be seen in eqn. 5 that represents the long and short run effect in the same formulation.

$$
\begin{aligned}
& \Delta \operatorname{lnprod}_{t}=\alpha+\beta_{0} \operatorname{lnprod}_{t-1}+\beta_{1} \operatorname{lnexp}_{t-1}^{+}+\beta_{2} \operatorname{lnexp}_{t-1}^{-}+\beta_{3} \operatorname{lnopen}_{t-1}+ \\
& +\beta 4 \operatorname{lngrw}_{t-1}+\beta_{5} \operatorname{lnhour~}_{t-1}+\sum_{i=1}^{p} \varphi_{i} \Delta \operatorname{lnprod}_{t-1}+\sum_{i=1}^{s}\left(\theta_{i}^{+} \Delta \operatorname{lnexp}_{t-\mathrm{i}}^{+}+\right. \\
& \left.+\theta_{i}^{-} \Delta \operatorname{lnexp}_{t-\mathrm{i}}^{-}\right)+\sum_{i=1}^{q} \gamma_{i} \Delta \operatorname{lnopen}_{t-i}+\sum_{i=1}^{r} \delta_{i} \Delta \operatorname{lngrw}_{t-i}+ \\
& +\sum_{i=1}^{w} \rho_{i} \Delta \operatorname{lnhour}_{t-i}+\mu_{t}
\end{aligned}
$$

The bounds testing approach (BTA) is proposed by Pesaran et al., (2001) irrespective of the fact that the variables are either purely I (0) or purely I (1), and mutually cointegrated. The null hypothesis of "no cointegration" given by 
$\beta_{0}=\beta_{1}=\beta_{2}=\beta_{3}=\beta_{4}=\beta_{5}=0$ in Eq. (5). The null hypothesis can be tested by using F-stats. If the computed statistics falls below the lower bound it means variables are I ( 0$)$ and no cointegration is possible. If it exceeds the upper bound, it suggests cointegration. If it falls within lower and upper bounds, inference is inconclusive. Akaike Information criteria and Schwarz Information criteria are used to determine the optimal number of lags in both linear-nonlinear ARDL model.

The implementation steps of the nonlinear ARDL model can be summarized as follows.

It is first necessary to perform unit root tests regardless of whether the variables are I (0) or I (1). Variables in the dataset should not have I (2) behavior. For this reason, $\mathrm{ADF}$ and PP tests were applied to investigate the orders of integration of variables. Secondly, the equation 5 is estimated by using ordinary least square method. Based on the estimated nonlinear model, the cointegration between variables was investigated by conducting the bound testing approach developed by Pesaran et al., (2001) and Shin et al., (2014). This is the Wald F test that the null hypothesis is $\beta_{0}=\beta_{1}=\beta_{2}=\beta_{3}=\beta_{4}=\beta_{5}=0$. In the last step, the results obtained are interpreted and deductions made.

\section{Empirical data and analysis}

In the empirical model it is applied both linear and non-linear ARDL model to investigate the relationship between labor productivity and government educational expenditure, openness ( $\%$ of GDP), GDP growth, average annual working hours. The data set belong to selected variables is yearly figures covering the period 19712015. The time series data obtained from World Bank and United Nations (UN) data service. The variable definitions is as follows in Table 1.

Table 1: Variable definitions

\begin{tabular}{|l|c|l|c|}
\hline \multicolumn{1}{|c|}{ Variables } & Code & \multicolumn{1}{c|}{ Definition } & Source \\
\hline Labor productivity & lnprod & Labor productivity in Manufacturing Sector & World bank \\
\hline Educational expenditure & lnexp & $\begin{array}{l}\text { Government expenditure on education (US } \\
\text { Dollars) }\end{array}$ & World bank \\
\hline Partial sum of expenditure & lnexp $^{+}$ & Positive changes in educational expenditure & World bank \\
\hline Partial sum of expenditure & lnexp $^{-}$ & $\begin{array}{l}\text { Negative changes in educational } \\
\text { expenditure }\end{array}$ & World bank \\
\hline Openness & lnopen $^{\text {Sum of Import and Export (\%GDP) }}$ & World bank \\
\hline Growth rate & lngrw & Annual GDP growth rate & World bank \\
\hline Working hours & lnhour & $\begin{array}{l}\text { Average annual hours actually worked per } \\
\text { worker in Manufacturing Sector }\end{array}$ & UN databank \\
\hline
\end{tabular}

Source: Authors' calculations 
In this part of the study, it is first applied to Augmented Dickey Fuller (ADF) and Philips Perron Unit Root Test in order to perform the bound testing procedure that no I(2) variables involved. The result of the unit root test can be seen in Table 2. It is included both constant and trend terms. As seen in Table 1, all variables have I( 0$)$ or I(1) behavior.

Table 2: ADF and PP Unit Root Tests

\begin{tabular}{|c|c|c|c|c|}
\hline Variables (in log) & Level ADF & PP & In first difference ADF & PP \\
\hline lnhour & $-7.817^{*}$ & $-7.850^{*}$ & $-6.331^{*}$ & $-54.816^{*}$ \\
\hline lnexp & -2.494 & -2.684 & $-6.413^{*}$ & $-6.413^{*}$ \\
\hline Inexp & -2.050 & -2.155 & $-6.682^{*}$ & $-6.682^{*}$ \\
\hline Inexp & -1.427 & -1.318 & $-7.584^{*}$ & $-7.584^{*}$ \\
\hline lnopen & $-5.140^{*}$ & $-5.135^{*}$ & $-9.840^{*}$ & $-20.047^{*}$ \\
\hline Ingrw & $-7.113^{*}$ & $-7.241^{*}$ & $-11.890^{*}$ & $-31.387^{*}$ \\
\hline Inhour & -1.895 & -1.929 & $-6.251^{*}$ & $-6.254^{*}$ \\
\hline
\end{tabular}

Note: The constant and trend terms are included and the SIC is selected to determine the optimal lag length in $\mathrm{ADF}$ test equation.

${ }^{*}$ denotes significance at $1 \%$ level.

Source: Authors' calculations

After determining the orders of integration for all variables, it can be proceed the bound testing procedure. The bound testing procedure suggest critical upper and lower values coming from Pesaran et al., (2001) to investigate whether there exist long-run relationship between variables for both models. Table 3 report the F-statistics of bound tests.

Table 3: Bound tests for linear non-linear cointegration

\begin{tabular}{|c|c|c|c|c|}
\hline \multirow{2}{*}{ Linear ARDL } & F stat. & $95 \%$ lower bound & $95 \%$ upper bounds & Decision \\
\cline { 2 - 5 } & 16,014 & 3,05 & 3,97 & Cointegration \\
\hline \multirow{2}{*}{ Non-linear ARDL } & F stat. & $95 \%$ lower bound & $95 \%$ upper bounds & Decision \\
\cline { 2 - 5 } & 16.978 & 2,81 & 3,76 & Cointegration \\
\hline
\end{tabular}

Source: Authors' calculations

As it can be seen in table 3 from the bounds F-statistics; there has been co moving for selected variables in the long-run. The F-statistics 16,014 and 16,978 for respectively linear and non-linear ARDL model exceed the critical upper bound. It is also applied Wald test to investigate whether the long-run reaction of labor productivity is asymmetric with respect to positive and negative changes of government educational expenditure. The null hypotheses of Wald test is $\beta_{1}=\beta_{2}$. 
Table 4: Estimation parameters of linear and non-linear models

\begin{tabular}{|c|c|c|c|c|c|c|c|c|c|}
\hline \multicolumn{10}{|c|}{$\begin{array}{l}\text { Part I: Estimation of the linear ARDL model } \\
\text { Panel A: Short run estimates }\end{array}$} \\
\hline & \multicolumn{9}{|c|}{ Lags } \\
\hline & 0 & 1 & 2 & 3 & 4 & 5 & 6 & 7 & 8 \\
\hline$\Delta$ lnprod & & $\begin{array}{l}0,278^{* *} \\
(2,699)\end{array}$ & $\begin{array}{c}0,093 \\
(1,476)\end{array}$ & & & & & & \\
\hline$\Delta \operatorname{lnexp}$ & $\begin{array}{c}-0,157^{* * *} \\
(-1,890)\end{array}$ & $\begin{array}{l}-0,281^{* *} \\
(-2,738)\end{array}$ & $\begin{array}{c}-0,392^{*} \\
(-3,900)\end{array}$ & $\begin{array}{c}-0,394^{*} \\
(-3,928)\end{array}$ & & & & & \\
\hline Slnopen & $\begin{array}{c}-0,114^{* * *} \\
(-2,046)\end{array}$ & $\begin{array}{c}-0,228^{*} \\
(-3,711)\end{array}$ & $\begin{array}{c}-0,686^{*} \\
(-13,253)\end{array}$ & & & & & & \\
\hline$\Delta \operatorname{lngrw}$ & $\begin{array}{c}0,460^{*} \\
(14,103)\end{array}$ & $\begin{array}{c}-0,121^{* * *} \\
(-1,735)\end{array}$ & $\begin{array}{c}0,012 \\
(0,216)\end{array}$ & $\begin{array}{c}0,105^{*} \\
(3,701)\end{array}$ & & & & & \\
\hline$\Delta$ lnhour & $\begin{array}{c}-6,706^{*} \\
(-3,220)\end{array}$ & $\begin{array}{c}-0,337 \\
(-0,158)\end{array}$ & $\begin{array}{l}-4,790^{* *} \\
(-2,330)\end{array}$ & & & & & & \\
\hline constant & $\begin{array}{l}-56,578^{*} \\
(-11,053)\end{array}$ & & & & & & & & \\
\hline \multicolumn{10}{|c|}{ Panel B: Long run estimates } \\
\hline \multicolumn{2}{|c|}{$\begin{array}{l}\text { lnexp } \\
\text { lnopen } \\
\text { lngrw } \\
\text { lnhour }\end{array}$} & \multicolumn{8}{|c|}{$\begin{array}{c}-0,187^{* *}(-2,099) \\
-0,100(-0,821) \\
0,488^{*}(5,437) \\
5,702^{*}(5,824)\end{array}$} \\
\hline \multicolumn{10}{|c|}{ Panel C: Diagnostic statistics } \\
\hline & & & ARCH & CUSM & CUSM $^{2}$ & LM Test & Adj. $R^{2}$ & $E C M_{t-1}$ & \\
\hline & & & 0,478 & $\mathrm{~S}$ & $\mathrm{~S}$ & 1,951 & 0,94 & $\begin{array}{c}-1,502^{*} \\
(-11,080)\end{array}$ & \\
\hline \multicolumn{10}{|c|}{$\begin{array}{l}\text { Part II: Estimation of the non-linear ARDL model } \\
\text { Panel A: Short run estimates }\end{array}$} \\
\hline & \multicolumn{9}{|c|}{ Lags } \\
\hline & 0 & 1 & 2 & 3 & 4 & 5 & 6 & 7 & 8 \\
\hline$\Delta$ lnprod & & $\begin{array}{c}1,273^{*} \\
(11,219)\end{array}$ & $\begin{array}{c}0,252^{*} \\
(5,982)\end{array}$ & $\begin{array}{c}0,139^{*} \\
(5,938)\end{array}$ & & & & & \\
\hline $\begin{array}{l}\Delta \ln \exp ^{+} \\
\Delta \ln \exp ^{-}\end{array}$ & \begin{tabular}{|c|}
$0.446^{*}$ \\
$(8,089)$ \\
$-1.202^{*}$ \\
$(-8,110)$ \\
\end{tabular} & $\begin{array}{c}1,065^{*} \\
(10,636) \\
-3.010^{*} \\
(-15,757) \\
\end{array}$ & $\begin{array}{c}0,670^{*} \\
(7,819) \\
-2,603^{*} \\
(-15,188) \\
\end{array}$ & $\begin{array}{c}0,451^{*} \\
(4,538) \\
-1,809^{*} \\
(-9,086) \\
\end{array}$ & \begin{tabular}{|c|}
$0,267^{* *}$ \\
$(2,558)$ \\
$-0,289$ \\
$(-1,523)$ \\
\end{tabular} & & & & \\
\hline$\Delta$ lnopen & $\begin{array}{l}0,109^{* *} \\
(3,113)\end{array}$ & $\begin{array}{c}-2,041^{*} \\
(-15,049)\end{array}$ & $\begin{array}{c}-2,032^{*} \\
(-18,815)\end{array}$ & $\begin{array}{c}-1,162^{*} \\
(-9,440)\end{array}$ & $\begin{array}{c}-1,082^{*} \\
(-11,148)\end{array}$ & & & & \\
\hline$\Delta \operatorname{lngrw}$ & $\begin{array}{c}0,620^{*} \\
(28,854)\end{array}$ & $\begin{array}{c}-0,730^{*} \\
(-12,335)\end{array}$ & $\begin{array}{l}-0,161^{*} \\
(-5,674)\end{array}$ & & & & & & \\
\hline$\Delta$ lnhour & $\begin{array}{l}-18,592^{*} \\
(-12,521)\end{array}$ & $\begin{array}{l}-4,896^{* *} \\
(-2,985)\end{array}$ & $\begin{array}{c}-9,861^{*} \\
(-6,502)\end{array}$ & $\begin{array}{c}15,550^{*} \\
(10,943)\end{array}$ & $\begin{array}{l}10.329^{*} \\
(7,601)\end{array}$ & & & & \\
\hline constant & $\begin{array}{l}-41,305^{*} \\
(-16,152)\end{array}$ & & & & & & & & \\
\hline
\end{tabular}




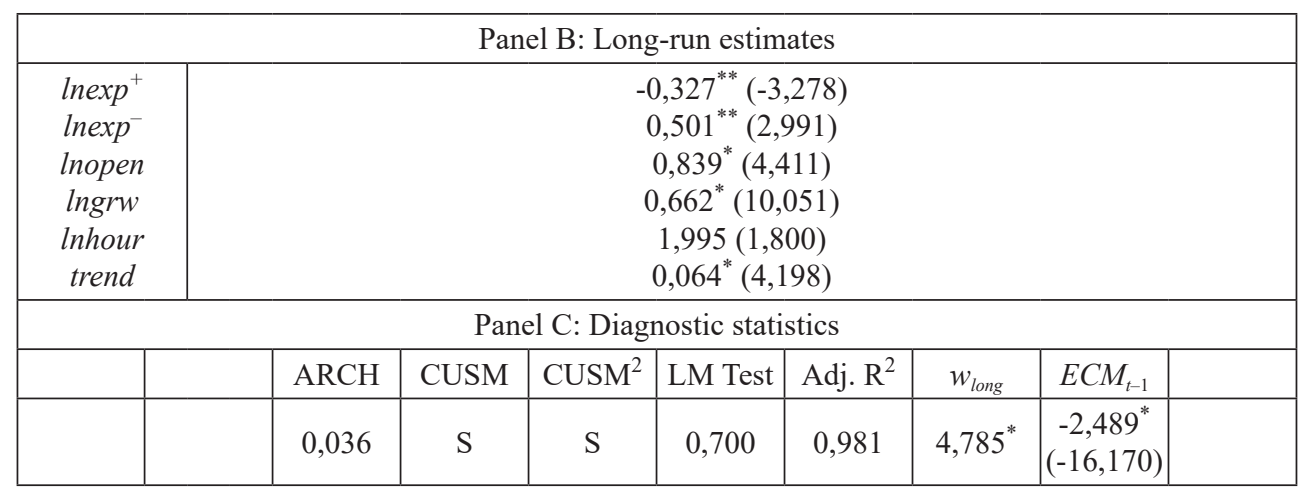

t statistics in parentheses; ${ }^{*}$ denotes significance at $1 \%$ level; ${ }^{* *}$ denotes significance at $5 \%$ level;

*** denotes significance at $10 \%$ level

Source: Authors' calculations

The Wald statistics reported in Table 3 as $W_{\text {long }}$ and it is statistically significant that suggest long run asymmetry.

Before making an inference by using estimated models additional diagnostic tests conducted as presented in Table 4. In order to test serial correlation in the presence of lagged variable it is applied Breusch Godfrey serial correlation LM test. LM statistics are not significant that means, estimated residuals are not correlated for both model. ARCH statistics for autoregressive conditional heteroscedasticity up to order 2. It is also investigated the structural stability by using CUSUM and CUSUMSQ statistics that names as S (stable) UnS (unstable). The estimated models passes all diagnostics tests suggest that absence of autocorrelation, parameter stability and heteroscedasticity. As a conclusion, the estimated models correctly and adequately specified.

\section{Results and discussion}

It is applied both linear and non-linear ARDL model to investigate the symmetricasymmetric relationship between labor productivity and government educational expenditure Besides the supportive results of the studies in the literature, different results were obtained. Descriptive tests have been carried out so that models can produce valid and reliable estimates. According to the test results, it could not be found any specification error or violation of assumptions. In the estimates obtained with the non-linear model, the investigation of the existence of asymmetric relationships suggests that the application of this model will produce more valid results. Changes in government educational expenditure (both increase and decrease) have a significant effect on labor productivity, and consequently, only the investigation of symmetric 
relationships will not be sufficient. The results obtained contribute to the filling of an important gap by bringing a different perspective to the relevant literature.

According to the linear model results, long run coefficient of lnexp and lnopen is negative, lngrw and lnhour is positive. All long-run coefficients are statistically significant except lnexp lnopen at 5\% significance level. Short-run coefficients of lnexp, lnopen, lngrw and lnhour are negative and statistically significant except lnhour for first lag. Linear model passed all the diagnostic tests successfully so the linear model is correctly specified.

In the non-linear model, the long-run coefficient of $\ln \exp ^{+}$is negative and statistically significant, lnexp, lnopen, lngrw and lnhour are positive and statistically significant except lnhour. Statistical significance level can be different for variables, so it could be better to examine Table 4 for the entire information. According to the non-linear model, there is also long run asymmetric relationships on productivity.

As can be seen in Table 4, there has been long run asymmetry. For this reason, it is possible to say that the non-linear ARDL model has a better ability to estimate the effect of government educational expenditure on labor productivity.

As a results; it is investigated the effects of negative and positive changes in government educational expenditures, besides government educational expenditure on labor productivity. For the investigation of the mentioned effects, it is applied linear and non-linear ARDL approach and the results are discussed. It is considered that the interpretation of this model is more accurate since the existence of the asymmetric effect is determined by the non-linear ARDL approach.

In addition to the studies emphasizing that there is no significant relationship between government educational expenditures and labor productivity in manufacturing sector, there are also studies showing that there is a negative relationship. Some of these studies suggest that government educational expenditure is not only for investment purposes but also for consumption purposes, and that consumption expenditures are not directly related to labor productivity, or have a crowding-out effect. When we examine the budget of the public sector in which education is allocated, it is seen that approximately $80 \%$ is divided into personnel expenses such as salaries and insurance premiums. In other words, a large part of the budget is not used in a way that affects labor productivity positively. The results obtained in the study also support this situation. As mentioned earlier, it is emphasized that there is a positive relationship between government educational expenditures, which are indicators of human capital stock in the endogenous growth models, and labor productivity in short-long run. This hypothesis has been partially confirmed; in the short run, there is a positive and significant relationship between increases in government educational expenditures $\left(\ln \exp ^{+}\right)$and labor productivity, while there is a positive and significant relationship between decreases in government educational expenditures $\left(\ln \exp ^{-}\right)$and labor productivity. On the other hand, there was a 
negative and significant relationship between increases in government educational expenditures $\left(\ln \exp ^{+}\right)$and labor productivity in the long run, and a positive and significant relationship between decreases in government educational expenditures ( $\operatorname{lnexp}^{-}$) and labor productivity in the long run. The expectation for the coefficients of the relevant variables $\alpha_{1}>\alpha_{2}$ (Eq. 2) is not confirmed.

Studies in the literature have shown that trade openness have significant effects on factor productivity, including labor. Turkey is followed by an economic growth model based on exports. In addition, raw materials and intermediate goods needed in the production process are also imported through imports. When these two conditions are evaluated together, it is expected that the level of openness of the economy will increase the labor productivity. The findings also show that trade openness has significant effects on labor productivity both in the short run and in the long run. A positive and significant relationship was found between trade openness (lnopen) and labor productivity as expected in the short and long run.

\section{Conclusion}

In this study which investigated the linear and nonlinear relationship between labor productivity and government educational expenditures; The effects of short and long run relations are examined separately. To this aim, the linear and nonlinear autoregressive distributed lag model is applied. According to the results, an asymmetric relationship between government educational expenditures and labor productivity was determined and therefore non-linear model was preferred. Although much of the work done in the economic literature focuses on the effects of labor productivity on economic growth, the effects of economic growth on labor productivity are also discussed. In this sense, the findings show that there is a positive and significant relationship between labor productivity and GDP growth in the long run, and a negative and significant relationship in the short run lags. Although the long-run coefficient for working hours is positive, it is not statistically significant. Short run coefficients are negative and significant for the first two lags; positive and significant for the last two lags. From this point of view, the increase in working hours in the manufacturing industry is reflected as an efficiency increase as a result of a certain adaptation process. The long run coefficient of openness is significantly positive; the short run coefficient of it is significantly negative for all lags. Overall, our findings are not in line with relevant literature on emerging economies, where government educational expenditure returns are linear and increase labor productivity. For the further research, different data set, different econometric models and different variable combinations can be used. In addition, some artificial intelligence techniques such as support vector machine/regression or artificial neural network can be used to estimate the nonlinear relations. It would be useful to estimate the effect of government educational expenditure on labour productivity for different sectors and compare the effects each other. 


\section{References}

Aleš, K., Nedomlelová, I. (2018) "Three Levels of Education and The Economic Growth”, Applied Economics, Vol. 50, No. 19, pp. 2103-2116, doi: 10.1080/ 00036846.2017.1388910.

Appiah, E. N. (2017) "The Effect of Education Expenditure on Per Capita GDP in Developing Countries", International Journal of Economics and Finance, Vol. 9, No. 10, pp. 136-144, doi: 10.5539/ijef.v9n10p136.

Appiah, E. N., McMahon, W. W. (2002) "The Social Outcomes of Education and Feedbacks on Growth in Africa", Journal of Development Studies, Vol. 38, No. 4, pp. 27-68, doi: 10.1080/00220380412331322411.

Azariadis, C., Drazen, A. (1990) "Threshold Externalities in Economic Development", Quarterly Journal of Economics, Vol. 105, No. pp. 501-526, doi: 10.2307/2937797.

Barro, R.J., Sala-I-Martin, X. (2004) Economic Growth. MIT Press, Cambridge, MA.

Becker, G. (1964) Human Capital New York: Columbia University Press.

Benos, N., Karagiannis, S. (2016) "Do Education Quality and Spillovers Matter? Evidence on Human Capital and Productivity in Greece", Economic Modelling, Vol. 54, No. 2016, pp. 563-573, doi: 10.1016/j.econmod.2016.01.015.

Blankenau, W., Simpson, N., Tomljanovich, M. (2007) "Public Education Expenditures, Taxation, and Growth: Linking Data to Theory", American Economic Review, Vol. 97, No. 2, pp. 393-397, doi: 10.1257/aer.97.2.393.

Bokana, G. K., Akinola, G. W. (2017) "Productivity Effects of Higher Education Human Capital in Selected Countries of Sub-Saharan Africa", Zb. rad. Ekon. fak. Rij., Vol. 35, No.1, pp. 173-198, doi: 10.18045/zbefri.2017.1.173.

Cass, D. (1965) "Optimum Growth in An Aggregative Model of Capital Accumulation", Review of Economic Studies, Vol. 32, No. 3, pp. 233-40, doi: $10.2307 / 2295827$.

Çalışkan, Ş., Karabacak M., Meçik, O. (2017) “Türkiye Ekonomisinde Eğitim Harcamaları ve Ekonomik Büyüme İlişkisi: Bootstrap Toda-Yamamoto Nedensellik Testi Yaklaşımı", KOSBED, Vol. 33, pp. 45-56.

Çoban, O. (2004) "Beşeri Sermayenin İktisadi Büyüme Üzerindeki Etkisi: Türkiye Örneği”, İstanbul Üniversitesi Siyasal Bilgiler Fakültesi Dergisi, Vol. 30, pp. $131-142$.

Demir, O., Üzümcü, A., Duran, S. (2006) "İçsel Büyümede İçselleşme Süreçleri: Türkiye Örneği”, Dokuz Eylül Üniversitesi İktisadi ve İdari Bilimler Fakültesi Dergisi", Vol. 21, No. 1, pp. 27-46.

Devarajan, S., Swaroop, V., Zou, H. (1996) "The Composition of Public Expenditure and Economic Growth", Journal of Monetary Economics, Vol. 37, pp. 313-344, doi: 10.1016/S0304-3932(96)90039-2. 
Eriçok, R. E., Yılancı, V. (2013) "Eğitim Harcamaları ve Ekonomik Büyüme İlişkisi: Sınır Testi Yaklaşımı”, Bilgi Ekonomisi ve Yönetimi Dergisi, Vol. 8, No. 1, pp. 87-101.

Griliches, Z. (1997) "Education, Human capital and Growth: a Personal Perspective", Journal of Labor Economics, Vol. 5, No. 1, pp. 330-344, doi: $10.1086 / 209865$.

Ifa, A., Guetat, I. (2018) "Does Public Expenditure on Education Promote Tunisian and Moroccan GDP per Capita? ARDL approach", The Journal of Finance and Data Science xx (2018), pp. 1-13, doi: 10.1016/j.jfds.2018.02.005.

Kocourek, A., Nedomlelová, I. (2018). "Three levels of education and the economic growth", Applied Economics, Vol. 50, No. 19, pp. 2103-2116, doi: 10.1080/00036846.2017.1388910.

Koopmans, T. C. (1965) "On The Concept of Optimal Economic Growth". In Johansen, J. ed., Econometric Approach To Development Planning, Netherlands: North-Holland Publishing Company.

Krueger, A. B., Lindahl, M. (2001) "Education for Growth: Why and for Whom?", Journal of Economics Literature, Vol. 39, No. 4, pp. 1101-1136, doi: 10.1257/ jel.39.4.1101.

Lucas R. (1990) "Why Doesn't Capital Flow from Rich to Poor Countries?", American Economic Review, Vol. 80, No. 2, pp. 92-96, doi: http://www.jstor. org/stable/2006549.

Lucas, R. E. (1988) "On The Mechanics of Economic Development", Journal of Monetary. Economics, Vol. 22, No. 1, pp. 3-42, doi: 10.1016/0304-3932(88) 90168-7.

Mankiw, N. G., Romer, D., Weil, D. N. (1992) "A Contribution to the Empirics of Economic Growth", The Quarterly Journal of Economics, Vol. 107, No. 2, pp. 407-437, doi: 10.23 07/2118477.

Mincer, J. (1974) Schooling, Experience, and Earnings Nat. Bur. of Economic Research, New York.

Musila J., Belassi W. (2004) "The Impact of Education Expenditures on Economic Growth in Uganda: Evidence from Time Series Data", The Journal of Developing Areas, 38, No. 1, pp. 123-133, doi: 10.1353/jda.2005.0015.

Nelson, R. R., Phelps, S. E. (1966) "Investment in Humans, Technological Diffusion, and Economic Growth", American Economic Review, Vol. 56, No. 1-2, pp. 69-75, doi: http://www. jstor.org/stable/1821269.

Pelinescu, E. (2015) "The Impact of Human Capital On Economic Growth", Procedia Economics and Finance, Vol. 22, No. 2015, pp. 184-190, doi: 10.1016/ S2212-5671(15)00258-0.

Pesaran, M. H., \& Shin, Y. (1999) "An autoregressive Distributed Lag Modelling Approach to Cointegration Analysis". In S. Strom (Ed.), Econometrics and 
Economic Theory in the 20th Century: The Ragnar Frisch Centennial Symposium (1st ed., pp. 371-413). Cambridge: Cambridge University Press.

Pesaran, M. H., Shin, Y., \& Smith, R. J. (2001) "Bounds testing approaches to the analysis of level relationships", Journal of Applied Econometrics, Vol. 16, No. 3, pp. 289-326, doi: 10.1002/jae.616.

Pritchett, L. (2001) "Where Has All The Education Gone?", The World Bank Economic Review, Vol. 15, No. 3, pp. 367-391, doi: 10.1093/wber/15.3.367.

Psacharopoulos, G., Patrinos, H. A. (2004) "Returns to Investment in Education A Further Update", Education Economics, Vol. 12, No. 2, pp. 111-134, doi: 10.1080/0964529042000239140.

Romer, P. M. (1990) "Endogenous Technological Change", Journal of Political Economy, Vol. 98, No. 5, Part 2, pp. 71-102, pages.stern.nyu.edu/ promer/ Endogenous.pdf.

Samargandi, N. (2018) "Determinants of Labor Productivity in MENA Countries", Emerging Markets Finance and Trade, Vol. 54, No. 5, pp. 1063-1081, doi: 10.1080/1540496X.2017. 1418658.

Schultz, T. W. (1961) "Investment in Human Capital", American Economic Review, Vol. 51, No. 1, pp. 1-17, doi: http://www.jstor.org/stable/1813848.

Shin, Y., Yu, B., \& Greenwood-Nimmo, M. (2014) "Modelling Asymmetric Cointegration and Dynamic Multipliers in a Nonlinear ARDL Framework". In R. C. Sickles \& W. C. Horrace (Eds.), Festschrift in Honor of Peter Schmidt: Econometric Methods and Applications (pp. 281-314). New York, NY: Springer New York. doi: 10.1007/978-1-4899-8008-3_9.

Solow, R. M. (1956) "A Contribution To The Theory of Economic Growth", Quarterly Journal of Economics, Vol. 70, No. 1, pp. 65-94, doi: 10.2307/ 1884513.

Şen, H., Kaya, A., Alpaslan, B. (2018) "Education, Health, and Economic Growth Nexus: A Bootstrap Panel Granger Causality Analysis for Developing Countries", Sosyoekonomi, Vol. 26, No. 36, pp. 125-144, doi: 10.17233/ sosyoekonomi.2018.02.07.

Temple, J. (1999) “A Positive Effect of Human Capital on Growth", Economics Letters, Vol. 65, No. 1, pp. 131-134, doi: 10.1016/S0165-1765(99)00120-2.

Wahab, A. A. O. A., Kefeli, Z. (2017) "Modeling the Effect of Healthcare Expenditure and Education Expenditure on Labour Productivity: A Study on OIC Countries", Journal of Business and Economics Review, Vol. 2, No. 2, pp. $31-37$. 


\title{
Utjecaj vladinih rashoda za obrazovanje na produktivnost rada: ne-linearni ARDL pristup na turski proizvodni sektor ${ }^{1}$
}

\author{
Atakan Durmaz ${ }^{2}$, Hakan Pabuçcu ${ }^{3}$
}

\begin{abstract}
Sažetak
Produktivnost rada je vrlo važna pojava za održavanje održivog gospodarskog razvoja. Zapravo, u ekonomskoj literaturi mnogo je studija o određivanju čimbenika koji utječu na produktivnost rada. U ovom trenutku, ova studija ima za cilj istražiti odnos između produktivnosti rada $i$ državnih rashoda za obrazovanje pomoću podataka koji obuhvaćaju razdoblje od 1971-2015 za Tursku. U tu svrhu primjenjuje se linearni i nelinearni autoregresivni distribuirani model odmaka (ARDL). Korištenjem graničnog testa, istražuje se dugoročni odnos između varijabli. Primijenjena su oba modela kako bi se utvrdilo je li odnos između varijabli linearan ili nelinearan. Utvrđena je asimetrična veza između produktivnosti rada $i$ državnih izdataka za obrazovanje. Zbog toga je preferiran nelinearni model. Empirijski nalazi ukazuju da pozitivne promjene obrazovnih rashoda imaju negativan utjecaj na produktivnost rada, a negativne promjene obrazovnih rashoda imaju pozitivan učinak na produktivnost rada. Dugoročni koeficijent otvorenosti je signifikantno pozitivan dok je kratkoročni koeficijent značajno negativan za sva odstupanja. S druge strane, učinak rasta BDP-a na produktivnost rada i kratkoročno i dugoročno je signifikantno pozitivan. Iako je učinak prosječnih godišnjih radnih sati negativan za prva dva odstupanja, za posljednja dva odstupanja kratkoročno je značajno pozitivan, a dugoročno je pozitivan, ali ne i značajno.
\end{abstract}

Ključne riječi: produktivnost rada, otvorenost, državni rashodi za obrazovanje, ekonomski rast, nelinearni ARDL

JEL klasifikacija: D24, H52, J24, O47

${ }^{1}$ Ovaj rad je razrađena verzija istraživanja "Utjecaj vladinih obrazovnih izdataka na tursku produktivnost rada: vezani testni pristup" koji je predstavljen u "Međunarodnom kongresu o političkim, ekonomskim i društvenim studijama" koji je organiziran u Sarajevu između 19. i 22. svibnja 2017. godine.

2 Docent, Ekonomski fakultet, Sveučilište Bayburt, 69000 Bayburt, Turska. Znanstveni interes: migracija, tržište rada, međunarodna ekonomija. Tel.: +90 45821111 53/1496. E-mail: adurmaz@bayburt.edu.tr (osobaza kontakt).

${ }^{3}$ Docent, Ekonomski fakultet i administrativne znanosti, Odjel za poslovanje, Sveučilište Bayburt, 69000 Bayburt, Turska. Znanstveni interes: strojno učenje, neizrazita logika, analiza vremenskih serija.Tel.: +90458 21111 53/1403.E-mail: hpabuccu@bayburt.edu.tr. 